\title{
Effect of Black Seed (Nigella sativa) Ethanol Extract on the Expression of Hypoxia Inducible Factor-1a(HIF-1a) and Endothelial Nitric Oxide Synthase(eNOS) in Placenta of Preeclampsia Mice Model
}

\author{
Wasilul Haq $^{1 \star}$, I Wayan Agung ${ }^{1}$, Mokhammad Nooryanto', \\ Bambang Raharjo ${ }^{1}$, Siti Candra ${ }^{1}$
}

\author{
1Department of Obstetrics and Gynecology, dr. Saiful Anwar General Hospital, \\ Medical Faculty of Brawijaya University, Jalan JA. Suprapto No 2, Malang 65111, \\ East Java, Indonesia
}

\begin{abstract}
About 10-15\% of direct maternal death is caused by preeclampsia and eclampsia. The first stage pathogenesis of preeclampsia is indicated by an increase in HIF- $1 \alpha$ placenta and AT1-AA. The second stage of preeclampsia is indicated by a decrease of eNOS placenta expression. Black seed (Nigella sativa) has thymoquinone and thymol as the active substances has shown potential in the prevention and therapy of preeclampsia. The trial study used 30 pregnant mice (Mus musculus) randomly divided into six groups.Two groups was for control (positive and negative) and other 4 groups were for experimental treatment. Positive control and experiment groups were injected with severe preeclampsia serum in pregnant women.The serum-injected experimental mice group were administered with various doses of $N$. sativa ethanol extract $(500,1000,1500$, and $2000 \mathrm{mg} / \mathrm{kg} /$ day for each group). Mice with a blood pressure of $\geq 140 / 90 \mathrm{mmHg}$ and proteinuria of $\geq 10 \mu \mathrm{g} /$ day served as preeclampsia mice models. Treatment with ethanol extract of $N$. sativa was performed on days 15 to day 19 of gestation. Data were analyzed to compare the mean of HIF-1 $\alpha$ and eNOS, showing a significant effect of ethanol extract of $N$. sativa in various doses, decreasing the expression of HIF- $1 \alpha$ and increasing eNOS in preeclampsia mice models. The optimal dose for both was $1000 \mathrm{mg} / \mathrm{kg} / \mathrm{day}$. The results concluded that the $N$. sativa ethanol extract administration decreased the expression of HIF- $1 \alpha$ and increased eNOS expression in the placenta of preeclampsia mice models.

Keywords : eNOS placenta, ethanol extract of $N$. sativa, HIF-1 $\alpha$ placenta, preeclampsia.
\end{abstract}

International Journal of PharmTech Research, Vol.11, No.1, pp 74-81, (2018)

http://dx.doi.org/10.20902/IJPTR.2018.11108 


\section{Introduction and Experimental}

Preeclampsia and eclampsia is the main cause for about10-15\% maternal death after or during labor. According to the World Health Organization (WHO), hypertension during pregnancy causes more than 50,000 maternal deaths per year worldwide ${ }^{1}$ During late pregnancy, the decrease inuteroplacental circulation results in chronic uteroplacental hypoxia, which triggers the release of several chemokines and microvesicles and induces inflammatory processes by activating monocytes and neutrophils. In preeclampsia,the excessive expression of Hypoxia-Inducible Factor $1 \alpha$ (HIF-1 $\alpha$ ) occurs in the placenta due to the disruptionof oxygen-sensing, where an increase in HIF- $1 \alpha$ and changes in the oxygenation process occur in preeclampsia, especially early-onset type ${ }^{2}$.

The first phase of the pathogenesis of preeclampsia largely explains the onset of preeclampsia, which is characterized by the increased HIF- $1 \alpha$ in response to chronic hypoxia conditions, as well as the emergence of AT1-AA (Angiotensin II Type 1 receptor Auto Antibody) as a maladaptation immunological response. Impaired perfusion and placental dysfunction trigger the release of placental factors such as microvesiclesyncytiotrophoblast as well as dissolved anti-angiogenic factors including sFlt-1 and sENG, through an increase in TNF- $\alpha$ in chronic hypoxic conditions ${ }^{2,3}$.

The second stage describes the process of maternal inflammatory response and endothelial dysfunction, which underlies the emergence of the clinical manifestations of preeclampsia. In this stage, there is an increase in the inflammatory response that is marked by the activation of inflammatory cells with an increase ofthe transcription factor NF-kB, triggering the release of inflammatory mediators such as IL-1 $\beta$, IL-6, IL-8, and TNF- $\alpha^{2,4}$.

N. sativa (Nigella sativa) has been known among Muslim people for centuries as a medication for many diseases. Some studies have shown that an active ingredient inside the $N$. sativa, thymoquinone, can function as an anti-inflammatory by inhibiting the enzymescyclooxygenase (COX) andlipoxygenase (LOX) as well as inhibiting transcription factors such as NF-kBand TNF- $\alpha^{5}$. Moreover, $N$. sativa also has properties as an antioxidant that is quite potent and lowers blood pressure. Thymoquinone, dithymoquinone, and thymol, contained in $N$. sativa oil, can reduce free radicals and serve as antihypertensives ${ }^{6}$.

Therefore, researchers are interested in examining how the ethanol extract of $N$. sativaat various doses affects the expression of HIF-1 $\alpha$ (as a hypoxiaplacenta marker) and eNOS expression (as an increased inflammatory response marker) in the placenta of pregnant mice who had been injected with the serum of pregnant women suffering from severe preeclampsia.

\section{Experimental design}

The study design used here is pure experimental research (true experimental) with the post-test only control group design. The study used 30 pregnant mice with preeclampsia models based on previous research ${ }^{8}$, who were randomly divided into six groups. The negative control group contained pregnant mice that were given intraperitoneal injections of normal serum from pregnant women. Positive controls used pregnant mice that were given an intraperitoneal injection of the serum of preeclampsia pregnant women who were untreated, while the four treatment groups used pregnant mice that were injected with the serum of preeclampsia pregnant women; each group received the treatment of ethanol extract of $N$. sativa with doses of 500, 1000, 1500 , and $2000 \mathrm{mg} / \mathrm{kgBW} /$ day. Intraperitoneal injections of serum from thepregnant woman were given to pregnant mice on gestational days 10 and 11 as $0.1 \mathrm{cc}$. On the 15 th day, blood pressure and urine checks were performed. Mice with blood pressure $\geq 140 / 90 \mathrm{mmHg}$ and proteinuria $\geq 10 \mu \mathrm{g} / \mathrm{hr}$ served as a model of preeclampsia.

\section{Immunohistochemistry and data analyses}

Treatment with ethanol extract of $N$. sativawas performed on the $15^{\text {th }}$ to $19^{\text {th }}$ day of gestation. Then, the mice were sacrificed on the $20^{\text {th }}$ day by taking placenta samples from each to examine the expression of HIF- $1 \alpha$ and eNOS using immunohistochemical staining in each using anti-mice antibody HIF-1 $\alpha$ and eNOS. The results of immunohistochemical staining for each placenta sample were then observed under a light microscope $(\mathrm{M}=1000 \mathrm{x})$; the average number of cells expressed was calculated as the number of placental tissue cells stained with the chromagenDAB (brown color) per visual field. Then, the data were processed and analyzed using One Way ANOVA and linear regression tests. 


\section{Results}

\section{Effect of ethanol extracts of $N$. sativa to the expression of HIF-1 $\alpha$ placenta}

From the observed immunohistochemical staining to detect the effect of $N$. sativa on the expression of HIF-1 $\alpha$ in placenta, the negative control group $(\mathrm{KN})$ showed lighter staining with very few cells stained brown compared to the positive control group (KP), which had a dominant brown cell density. The number of cells in the placental tissue staining brown was gradually less in the treatment groups of $N$. sativawith doses of 1000 $\mathrm{mg} / \mathrm{kg} /$ day (P2), $1500 \mathrm{mg} / \mathrm{kg} /$ day (P3) and $2000 \mathrm{mg} / \mathrm{kg} /$ day (P4) compared to the positive control group (KP). The comparison of expression of HIF-1 $\alpha$ in the cytoplasm of placenta cells network is shown in Figure 1.

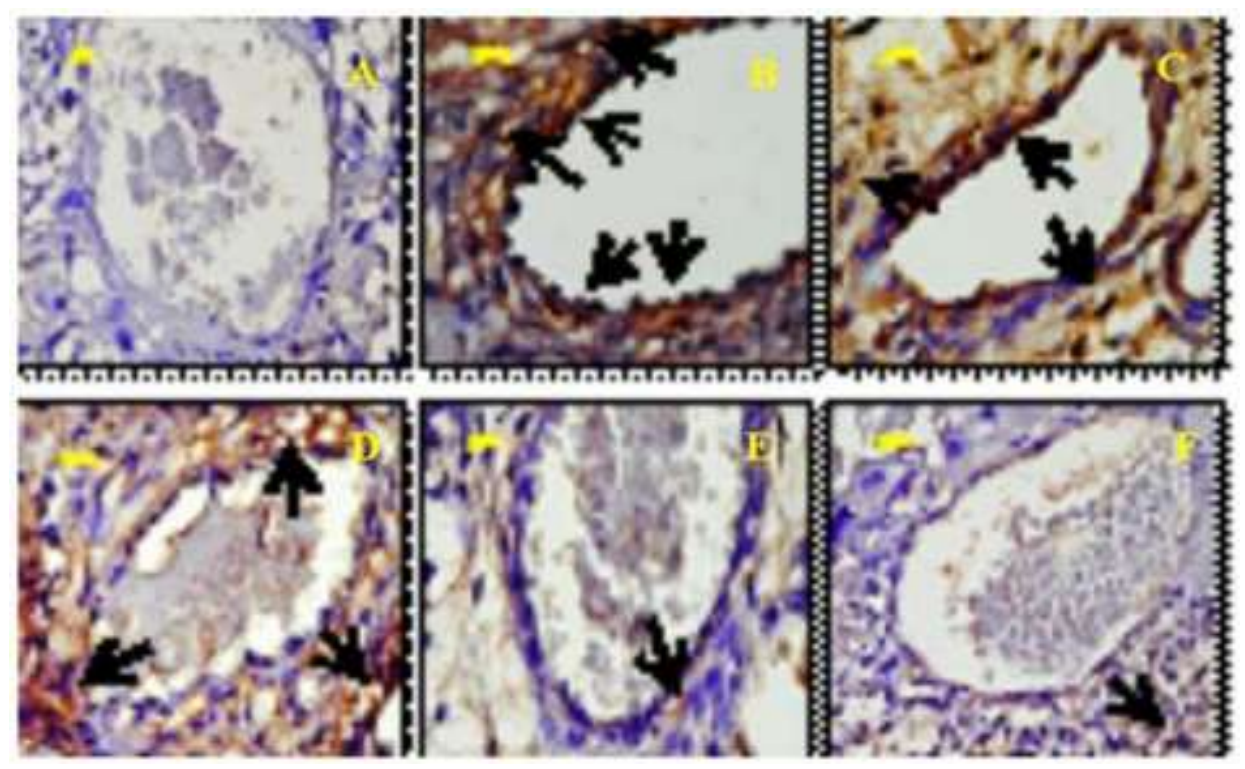

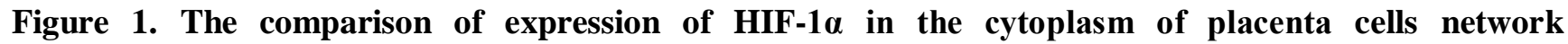
$(M=1000 x)$.Description: A. Negative control; B. Positive controls; $C$. The treatment group with dose of $500 \mathrm{mg} / \mathrm{kgBW} / \mathrm{day} ; \mathrm{D}$. The treatment group with dose of $1000 \mathrm{mg} / \mathrm{kgBW} / \mathrm{day}$; E. The treatment group with dose of $1500 \mathrm{mg} / \mathrm{kgBW} /$ day F. The treatment group with dose of $2000 \mathrm{mg} / \mathrm{kgBW} / \mathrm{day}$. Arrows: cellexpressed HIF-1a

After the average number of cells expressing HIF-1 $\alpha$ was calculated, it was analyzed using ANOVA with a $\mathrm{p}$-value of 0.000 , which is smaller than $\alpha=0.05(\mathrm{p}<0.05)$. Therefore, from this test, it can be concluded that there is a significant effect of ethanol extract of $N$. sativa on the expression of HIF-1 $\alpha$ placenta, in other words, there are significant differences in the placental expression of HIF-1 $\alpha$ as a result of ethanol extracts of $N$. sativa with different doses.

From the analysis of multiple comparisons using the 5\% HSD Tukey test, the ratio between the negative control group $(\mathrm{KN})$ and the positive control $(\mathrm{KP})$ showed a significant difference $(\mathrm{p}=0.000)$. This significant difference proves that the injection of serum from mothers with severe preeclampsia had an impact, by significantly increasing the expression of theHIF-1 $\alpha$ placenta.

In a comparison of the negative control group $(\mathrm{KN})$ with the treatment groups, the ethanol extract of $N$. sativa with doses of $1000 \mathrm{mg} / \mathrm{kg}$ (P2), $1500 \mathrm{mg} / \mathrm{kg}$ (P2) and $2000 \mathrm{mg} / \mathrm{kg}$ (P3) were able to decrease the expression of HIF- $1 \alpha$ in the placenta in healthy mice in the negative control group $(\mathrm{KN})$. The mean expression of HIF-1 $\alpha$ placenta control and treatment groups is shown in Figure 2. 


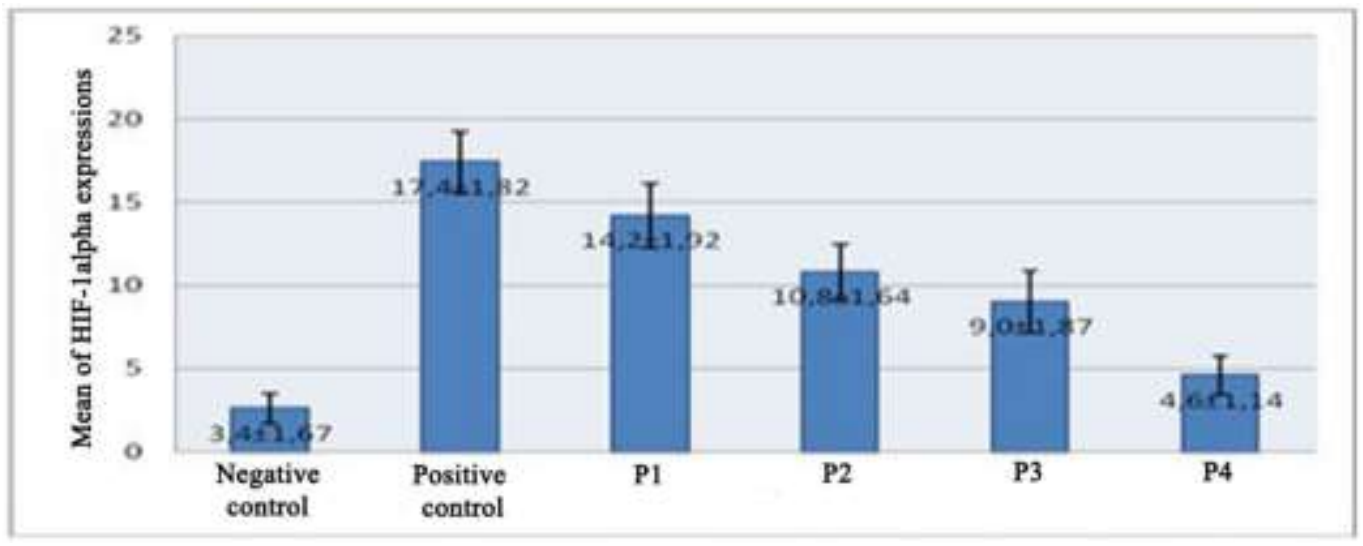

Figure 2. Mean expression of HIF-1 placenta. The histogram data shows that dose treatment group 1000 $\mathrm{mg} / \mathrm{kgBW}$ (P2), dose of $1500 \mathrm{mg} / \mathrm{kgBW}$ (P3), and dose of $2000 \mathrm{mg} / \mathrm{kgBW}$ (P4) had a mean expression of HIF-1 $\alpha$ placenta that did not differ significantly from the negative control group. P1: Treatment group with $500 \mathrm{mg} / \mathrm{kgBW}$ dose of $N$. sativa extracts.

The histogram data in Figure 2shows that the groups treated with $1000 \mathrm{mg} / \mathrm{kgBW}(\mathrm{P} 2), 1500 \mathrm{mg} / \mathrm{kgBW}$ (P3), and $2000 \mathrm{mg} / \mathrm{kgBW}(\mathrm{P} 4)$ had a mean expression of HIF-1 placenta that did not differ significantly from the negative control group, therefore, it is concluded that the optimum dose of ethanol extract of $N$. sativa is $1000 \mathrm{mg} / \mathrm{kgBW}$ because it is the minimum dose that is able to reduce the expression of HIF-1 $\alpha$ placenta, and did not differ significantly from the expression of HIF-1 $\alpha$ placenta in the negative control group.

\section{Effect of ethanol extracts of $N$. sativato the expression of eNOS placenta}

From the observation of the immunohistochemical staining to detect the effect of $N$. sativa on eNOS expression in the placenta, the negative control group $(\mathrm{KN})$ gave an image with a darker color, showing that the density of cells stained brown is dominant compared to the positive control group (KP), which looked very minimal. In contrast, the number of placental tissue cells stained brown was higher in the groups treated with $N$. sativa doses of $1000 \mathrm{mg} / \mathrm{kgBW} /$ day (P2), $1500 \mathrm{mg} / \mathrm{kgBW} / \mathrm{day}(\mathrm{P} 3)$ and $2000 \mathrm{mg} / \mathrm{kgBW} /$ day (P4) compared to the positive control group (KP). Based on observations of the negative control group (KN), darker staining was observed compared to the positive control group (KP). The number of placental tissue cells that were brown was higher in the treatment group of $N$. sativa with doses of $1000 \mathrm{mg} / \mathrm{kgBW} / \mathrm{day}(\mathrm{P} 2), 1500 \mathrm{mg} / \mathrm{kgBW} / \mathrm{day}(\mathrm{P} 3)$ and $2000 \mathrm{mg} / \mathrm{kgBW} /$ day (P4) compared to the positive control group (KP). The comparison of the expression of eNOS in the cytoplasm of placenta cells is shown in Figure 3.
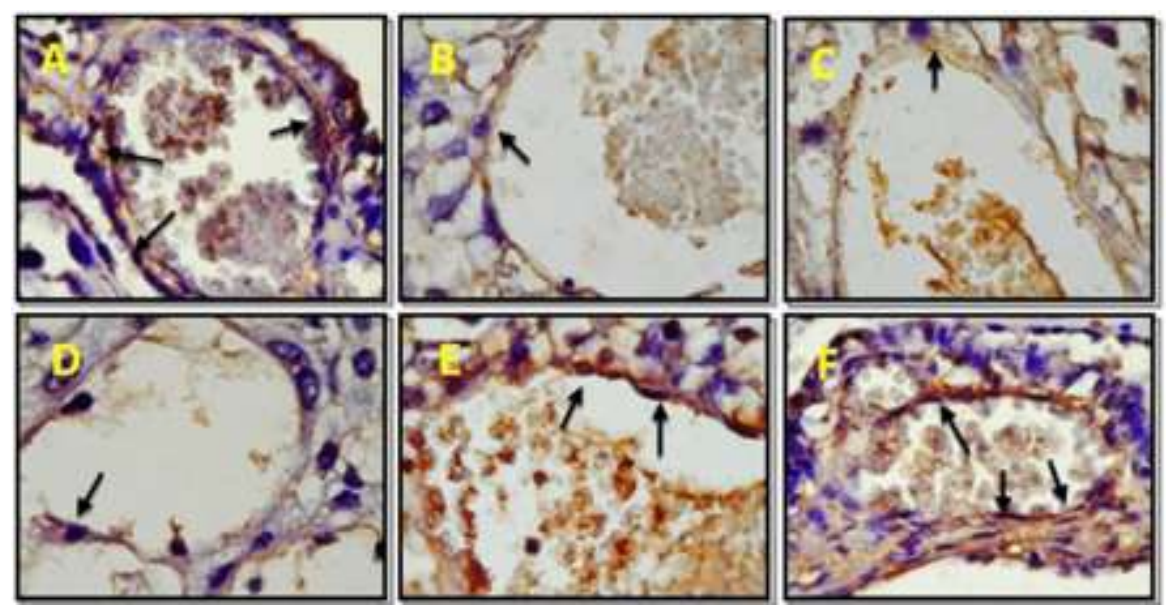

Figure 3. The comparison of expression of eNOS in the cytoplasm of placenta cells network $(M=1000 x)$. Description: A. Negative control; B. Positive controls; C. The treatment group dose of 500 $\mathrm{mg} / \mathrm{kgBW} / \mathrm{day}$; D. The treatment group dose of $1000 \mathrm{mg} / \mathrm{kgBW} / \mathrm{day}$; E.The treatment group dose of 1500 $\mathrm{mg} / \mathrm{kgBW} /$ day; F. The treatment group dose $2000 \mathrm{mg} / \mathrm{kgBW} / \mathrm{day}$. Arrows: cells expressed by eNOS 
After the average data of the number of cells expressed by eNOS were obtained, they were analyzed using ANOVA, with the $\mathrm{p}$-value of 0.000 , which was smaller than $\alpha=0.05(\mathrm{p}<0.05)$. Therefore, from this test, it can be concluded that $N$. sativa extract has a significant influence on the expression of Enos in the placenta, in other words, there are significant differences in the expression of eNOS in the placenta when the ethanol extract of $N$. sativais given at different doses.

In a comparison of the negative control group $(\mathrm{KN})$ with treatments, it was shown that the ethanol extract of $N$. sativaat doses of $1000 \mathrm{mg} / \mathrm{kgBW}$ (P2), $1500 \mathrm{mg} / \mathrm{kgBW}$ (P2) and $2000 \mathrm{mg} / \mathrm{kgBW}$ (P3) were able to increase the expression of eNOS placenta until close to a healthy micecondition in the negative control group $(\mathrm{KN})$. The mean of the eNOS placenta expression control group and the full treatment are shown in the histogram in Figure 4.

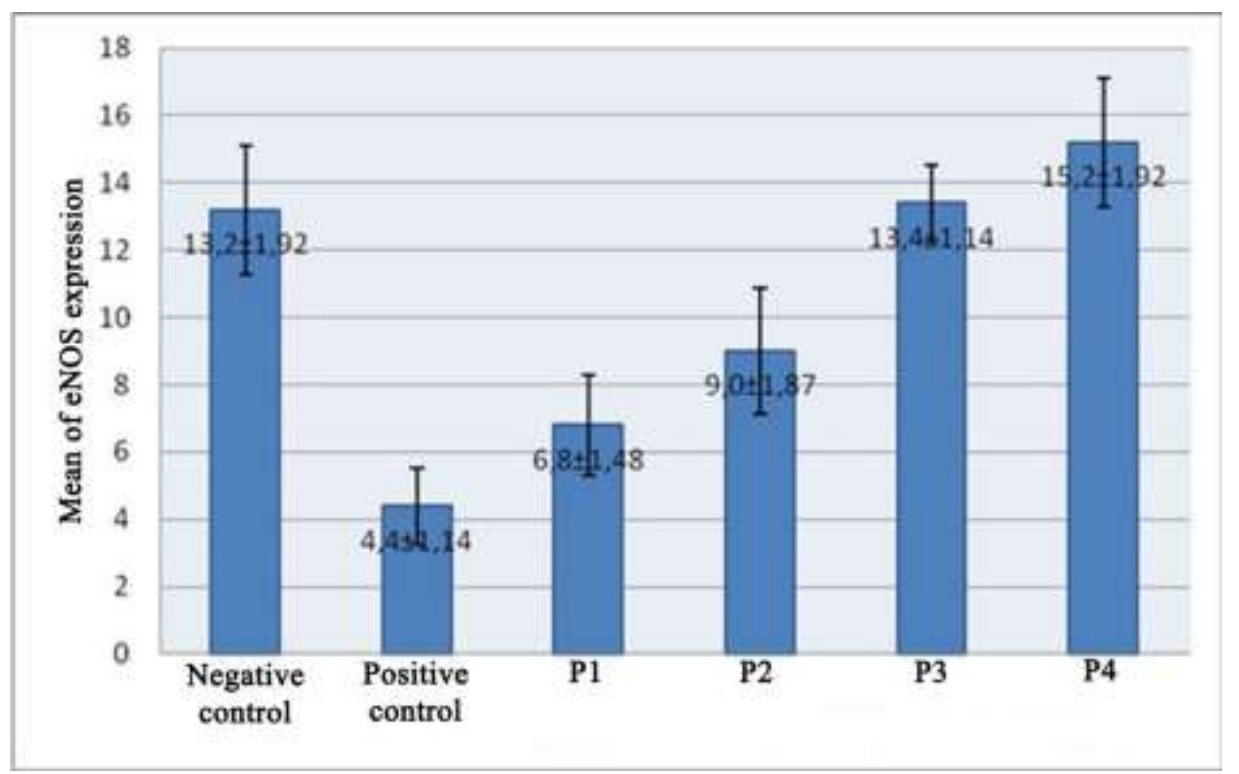

Figure 4. Mean expression of eNOS placenta. The histogram data shows that the dose treatment group $1000 \mathrm{mg} / \mathrm{kgBW}$ (P2), dose of $1500 \mathrm{mg} / \mathrm{kgBW}$ (P3), and dose of $2000 \mathrm{mg} / \mathrm{kgBW}$ (P4) had a mean expression of eNOS placenta that did not differ significantly with the negative control group. P1: Treatment group with $500 \mathrm{mg} / \mathrm{kgBW}$ dose of $N$. sativa extracts.

The histogram datain Figure 4 shows that the doses of $1000 \mathrm{mg} / \mathrm{kgBW}(\mathrm{P} 2), 1500 \mathrm{mg} / \mathrm{kgBW}$ (P3), and $2000 \mathrm{mg} / \mathrm{kgBW}$ (P4) resulted in a mean expression of eNOS placenta that did not differ significantly from the negative control group; therefore, it was concluded that the optimum dose of ethanol extract of N. sativa is 1000 $\mathrm{mg} / \mathrm{kgBW}$ because it is the minimum dose that is capable of increasing the expression of eNOS placenta that did not differ significantly from the results in the negative control group.

\section{Discussion}

This study has shown that the expression of theHIF-1 $\alpha$ placenta in pregnant mice injected with maternal serum preeclampsiawas significantly increased $(\mathrm{p}=0.000)$ compared to the mice in the negative control group. This shows that the distribution of intraperitoneal injection of preeclampsia can increase the expression of HIF$1 \alpha$ in the miceplacenta model of preeclampsia.

This was based on previous research, which showed that the serum of patients with preeclampsia can induce symptoms of preeclampsia in mice ${ }^{7}$. This isthe result of pre-eclamptic patient serum that can induce hypoxia in the mice placenta. Hypoxia that occurs in the mice placenta is the result of a disturbance in trophoblast invasion in the spiral arteries, which results in a disruption of arterialspiralis remodeling, resulting in placental ischemia. Placental hypoxia and ischemia induce the HIF-1 $\alpha$ accumulation in the placenta. This accumulation can be seen with the increased expression of HIF-1 $\alpha$ in the placental tissue ${ }^{7}$. This study was strengthened by the result of another research, where the intraperitoneal injection of serum from mothers withpreeclampsia, with serum containing high levels of TNF- $\alpha$, will increase the serum levels of sFlt-1 in pregnant mice. The increased levels of sFlt-1 are caused by the escalation of TNF- $\alpha$ to its receptors, stimulating 
the formation of HIF-1 by increasing the transcription of a subunit of HIF-1, HIF-1 $\alpha$. The HIF-1 protein acts as a transcriptional activator of sFlt- $1^{8}$.

In accordance with the above explanation, this study has shown that maternal serum injections of preeclampsia will increase the expression of HIF-1 $\alpha$, which in placental tissue from mice that have been injected with the serum of women with severe preeclampsia using HIF-1 $\alpha$ antibodies shows the accumulation in cells with brown color. The dominance of the brown color in the cells of placental tissue is particularly apparent fortrophoblast cells and also for endothelial cells from blood vessels in the placenta. This is consistent with previous studies showing that hypoxic conditions increased the expression of HIF-1 $\alpha$ in the placenta in preeclampsia $^{9-11}$.

The decreased expression of eNOSin the placenta of mice with preeclampsia in this study was also proven by another research ${ }^{8}$. As a result of the increase in serum sFlt-1 after the mice were given injections of high serum TNF- $\alpha$ from the blood of preeclamptic women, there was a decline of proangiogenic factors such as VEGF and PLGF. The decreased VEGF and PLGF will reduce the bond between VEGF to VEGFR-1 and VEGFR-2. The decrease in the activity of VEGFR-2 would result in a decrease in the activity of eNOS, resulting in the decreased synthesis of $\mathrm{NO}^{8}$.

The decreased expression of eNOS in the placenta of micepreeclampsia models is in accordance with previous studies, in which the trophoblast cells and the vascular endothelium of the placental tissues of preeclamptic patients have been decreased. The decrease in eNOS activity can be seen in endothelial cells from the blood vessels of the placenta, and also occurs in the cells of the syncytiotrophoblast ${ }^{12,13}$.

From the results of this study, it is clear that there are significant differences between the expression of HIF-1 $\alpha$ in the micemodel of preeclampsia (positive control) following treatment with ethanol extract of $N$. sativa with a p-value of $0.000(\mathrm{p}<0.05)$. This shows that the ethanol extract of $N$. sativa can decrease the expression of HIF$1 \alpha$ in themice placenta model of preeclampsia.

The way in which ethanol extract of $N$. sativaat various doses decreased the expression of HIF-1 $\alpha$ in the miceplacenta model of pre-eclampsia is not fully understood. However, it is suspected that the mechanism by which $N$. sativareduces the expression of HIF-1 $\alpha$ occurs through oxidative stress (decreased ROS) and inflammatory processes simultaneously through the inhibition of $\mathrm{NF}-\mathrm{KB}^{14,15}$. Thymoquinone as an active ingredient of $N$. sativaprevents the expression of the p65 subunit of NF- $\mathrm{KB}$ and minimizes the escalation of $\mathrm{p} 50$ subunit in vivo to the TNF- $\alpha$ promoter ${ }^{5}$. ROS are also known to be elevated in preeclampsia,as oxidative stress plays an important role in the NF- $\kappa \mathrm{B}$ pathway. Therefore, $N$. sativa disrupts this interaction by suppressing NF$\kappa \mathrm{B}$ and play an important role, showing anti-oxidant and anti-inflammatoryactivities ${ }^{14,16}$. With the decline of $\mathrm{NF}-\kappa \mathrm{B}$ and ROS, there were losses of TNF- $\alpha$ and other proinflammatorymarkers, resulting in the decreased production of HIF- $1 \alpha$ as a marker of placental hypoxia.

From the results of this study, it was shown that there are significant differences between the miceplacenta eNOS expression model of preeclampsia (positive control) and the group treated with ethanol extract of $N$. sativa, with a p-value of $0.000(\mathrm{p}<0.05)$. This shows that the ethanol extract of $N$. sativa can increase eNOS expression in the miceplacenta model of preeclampsia. Despite the increase in eNOS expression, the influence of ethanol extract of $N$. sativa on the miceplacenta model of preeclampsia has not been studied previously. However, previous studies have shown that the methanol fraction of $N$. sativa can increase the expression of iNOS and increase the production of $\mathrm{NO}^{17,18}$. It is therefore logical that iNOS and eNOSact as NO-producing enzymes, playing important roles in the pathogenesis of preeclampsia.

The mechanism responsible for the increase in eNOS expression in the miceplacenta model of preeclampsia is still not known. However, the allegedly potent antioxidant activity of $N$. sativa through its active component, thymoquinone, can obstruct ROS. The decline of free radicals such as ROS would result in an increase in proangiogenic factors such as VEGF, thereby increasing the activity of eNOS ${ }^{19,20}$.

Thymoquinone suppresses the activation of NF- $\mathrm{KB}$ by obstructing the activation, phosphorylation, and degradation of protein kinase $\mathrm{B}(1 \kappa \mathrm{B} \alpha)$, thereby obstructing the degradation and translocation of p65. A decrease in the activity of NF- $\mathrm{\kappa B}$ in patients with preeclampsia will increase proangiogenic factors and increase eNOS activity, both inendothelial cells of blood vessels and in placental trophoblast cells. The result is the 
increased production of $\mathrm{NO}$ and improved endothelial function, meaning that the symptoms of preeclampsia will gradually decline; this is characterized by a decrease in blood pressure and proteinuria ${ }^{14,21}$.

\section{Conclusion}

Intraperitoneal injection of preeclampsia maternal serum to pregnant mice may increase the expression of HIF- $1 \alpha$ and decrease the expression of eNOS in the placenta. Ethanol extracts of Nigella sativa can decrease the expression of HIF-1 $\alpha$ and increase eNOS expression in the miceplacenta model of preeclampsia.

\section{Acknowledgement}

Authors thank to Department of Obstetrics and Gynecology, dr. Saiful Anwar General Hospital, Medical Faculty of Brawijaya University, Malang, East Java, Indonesia for facilitating this study.

\section{Conflict of Interest}

Authors declare no conflicts of interest.

\section{References}

1. Sidani, M., \& Siddik-Sayyid, S. M. (2011). Preeclampsia, a new perspective in 2011. Middle East Journal of Anaesthesiology, 21, 207-214.

2. Laresgoiti-Servitje, E. (2013). A leading role for the immune system in the pathophysiology of preeclampsia. Journal of Leukocyte Biology, 94(2), 247-257. doi:10.1189/jlb.1112603.

3. Young, B. C., Levine, R. J., \& Karumanchi, S. A. (2010). Pathogenesis of preeclampsia. Annual Review of Pathology, 5(1), 173-192. doi:10.1146/annurev-pathol-121808-102149.

4. Cunningham, F., Leveno, K., Bloom, S., Hauth, J., Rouse, D., \& Spong, C. Williams Obstetricss, 23rd Edition, McGraw Hill, New York, 2010.

5. El Mezayen, R., El Gazzar, M., Nicolls, M. R., Marecki, J. C., Dreskin, S. C., \& Nomiyama, H. (2006). Effect of thymoquinone on cyclooxygenase expression and prostaglandin production in a mice model of allergic airway inflammation. Immunology Letters, 106(1), 72-81. doi:10.1016/j.imlet.2006.04.012.

6. Leong X.F., Rais M.M. and Jaarin K., (2013). Nigella sativa and its protective role in oxidative stress and hypertension, Evidence Based Complementary and Alternative Medicine, 2013, 120732.

7. Kalkunte, S., Boij, R., Norris, W., Friedman, J., Lai, Z., Kurtis, J., \& Sharma, S. (2010). Sera from preeclampsia patients elicit symptoms of human disease in mice and provide a basis for an in vitro predictive assay. American Journal of Pathology, 177(5), 2387-2398. doi:10.2353/ajpath.2010.100475.

8. Aji Wicaksono, B., Candra Windu Baktiyani, S., \& Enggar Fitri, L. (2015). Intraperitoneal injection of high Tumor Necrosis Factor (TNF- $\alpha$ ) serum increase soluble Fms-like tyrosine kinase-1 (sFlt-1) and blood pressure of pregnant mice. Journal of Tropical Life Science, 5(2), 60-64. doi:10.11594/jtls.05.02.01.

9. Rajakumar, A., \& Conrad, K. P. (2000). Expression, ontogeny, and regulation of hypoxia-inducible transcription factors in the human placenta 1. Biology of Reproduction, 63(2), 559-569. doi:10.1095/biolreprod63.2.559.

10. Zamudio, S., Wu, Y., Ietta, F., Rolfo, A., Cross, A., Wheeler, T., \& Caniggia, I. (2007). Human placental hypoxia-inducible factor-1 $\alpha$ expression correlates with clinical outcomes in chronic hypoxia in vivo. American Journal of Pathology, 170(6), 2171-2179. doi:10.2353/ajpath.2007.061185.

11. Tal, R. (2012). The role of hypoxia and hypoxia-inducible factor-1alpha in preeclampsia pathogenesis. Biology of Reproduction, 87(6), 134. doi:10.1095/biolreprod.112.102723.

12. Lee, C. N., Chang, S. W., Cho, N. H., \& Cho, S. H. (1997). Nitrous oxide synthase expression in placenta of preeclampsia. Journal of Korean Medical Science, 12(6), 532-538. doi:10.3346/jkms.1997.12.6.532.

13. Napolitano, M., Miceli, F., Calce, A., Vacca, A., Gulino, A., Apa, R., \& Lanzone, A. (2000). Expression and relationship between endothelin-1 messenger ribonucleic acid (mRNA) and inducible/endothelial nitric oxide synthase mRNA isoforms from normal and preeclamptic placentas. The Journal of Clinical Endocrinology and Metabolism, 85(6), 2318-2323. doi:10.1210/jcem.85.6.6623. 
14. Sethi, G., Ahn, K. S., \& Aggarwal, B. B. (2008). Targeting nuclear factor-кB activation pathway by thymoquinone: role in suppression of antiapoptotic gene products and enhancement of apoptosis. Molecular Cancer Research, 6(6), 1059-1070. doi:10.1158/1541-7786.MCR-07-2088.

15. Wilkins, R., Tucci, M., \& Benghuzzi, H. (2010). Role of plant-derived antioxidants on NF-kb expression in LPS-stimulated macrophages-biomed 2011. Biomedical Sciences Instrumentation, 47, 222-227.

16. Bayrak, O., Bavbek, N., Karatas, O. F., Bayrak, R., Catal, F., Cimentepe, E., . ., \& Akcay, A. (2008). Nigella sativa protects against ischaemia/reperfusion injury in rat kidneys. Nephrology, Dialysis, Transplantation, 23(7), 2206-2212. doi:10.1093/ndt/gfm953.

17. Fathy, M., \& Nikaido, T. (2013). In vivo modulation of iNOS pathway in hepatocellular carcinoma by Nigella sativa. Environmental Health and Preventive Medicine, 18(5), 377-385. doi:10.1007/s12199013-0336-8.

18. Tripathi, Y. B., Chaturvedi, A., \& Pandey, N. (2012). Effect of Nigella sativa seeds extracts on iNOS through antioxidant potential only: crude/total extract as molecular therapy drug. Indian Journal of Experimental Biology, 50, 413-418.

19. Amin, A., \& Owoyele, B. V. (2014). Exogenous administration of L-arginine enhances the antiinflammatory activity of Nigella sativa (blackseed) oil in wistar rats. Pharmacologyonline, 3, 112-120.

20. Meziti, A., Meziti, H., Boudiaf, K., Mustapha, B., \& Bouriche, H. (2012). Polyphenolic profile and antioxidant activities of Nigella sativa seed extracts in vitro and in vivo. World Academy of Science, Engineering and Technology, 64, 24-32.

21. Kulandavelu, S., Whiteley, K. J., Qu, D., Mu, J., Bainbridge, S. A., \& Adamson, S. L. (2012). Endothelial nitric oxide synthase deficiency reduces uterine blood flow, spiral artery elongation, and placental oxygenation in pregnant mice. Hypertension, 60(1), 231-238. doi:10.1161/HYPERTENSIONAHA.111.187559.

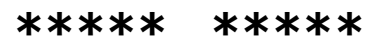

